\title{
EVALUATION OF THE VARIABILITY OF COMPRESSIVE STRENGTH PARALLEL TO THE FIBERS OF HARDWOOD SPECIES
}

\author{
Larissa Soriani Zanini Ribeiro Soares Silva ${ }^{1, \diamond}$, Felipi Pablo Damasceno Fernandes ${ }^{2}$, \\ Lucimar de Souza e Paula ${ }^{1}$, Francisco Antonio Rocco Lahr ${ }^{2}$
}

\begin{abstract}
Wood has several advantages as structural material. For this use to be applied in a safe way, it is necessary to know the statistical behavior of the mechanical properties. Some works and normative codes, such as the "Brazilian timber standard" (as well as its review project), accepts a normal distribution model for determining the characteristic value of compressive strength parallel to wood fiber, with the adoption of a coefficient of variation for this property equal to $18 \%$. This work evaluates the distribution model of compressive strength parallel to the fibers, as well as the coefficient of variation of this property. Tests and statistical treatment were performed in compression parallel to the fibers for 7 species of hardwood commonly found in Brazil. It was observed that the compressive strength of wood actually follows a normal distribution, and the adoption of an average coefficient of variation equal to $18 \%$ is acceptable and in favor of safety.
\end{abstract}

Keywords: Aspidosperma polyneuron, compression tests, Caryocar villosum, Goupia glabra, Hymenaea spp., Paratecoma peroba, Tabebuia serratifolia, Vochysia spp., wood properties.

\section{INTRODUCTION}

Timber is a material of natural origin with a wide variety of possibilities of use, including structural employment. Among the materials commonly used in structures, timber is renewable, has a high strength to weight ratio, and its production generates few environmental impacts.

To harness the advantages of timber as a structural material and to meet the structural performance requirements established by modern normative codes, it is necessary to know its mechanical properties as well as the variability of these properties.

Several studies present results related to the mechanical characterization of wood species and their variability, such as: Aquino et al. (2018), Couto et al. (2018), Gherardi Hein et al. (2012), Koman et al. (2017). Besides these, we can highlight the studies of Lima et al. (2018) and Silva et al. (2018) that evaluated the variability of physical and mechanical properties of wood as a function of the geographical origin, as well as the studies of Lima Junior et al. (2018) and Zeidler et al. (2014), which investigated the variability of the mechanical properties of wood extracted from different positions in a tree. When specifically evaluated the variability of compressive strength parallel to the wood fibers, Kretschmann (2010) has a mean coefficient of variation equal to $18 \%$. This value is also indicated by the Brazilian standard of timber structures, NBR 7190 (ABNT 1997), as well as in its review project, PNNBR 7190 (ABNT 2013b).

Another important factor in the use of timber in structures is the statistical distribution of its mechanical properties. It is usually considered the characteristic value of a certain strength as the value corresponds to the quantile of fifth percentile of the distribution of strengths. The distribution will influence the definition of the 
characteristic strengths.

The NBR 7190 (ABNT 1997) and UNE-EN 14358 (CEN 2016) allow the adoption of a normal or lognormal distribution for compressive strength parallel to the wood fibers. Some scientific studies evaluate both the variability of compressive strength parallel to the fibers of the wood, as to the form of its statistical distribution.

Espinosa et al. (2004) and Pinto et al. (2004) observed in a sample of Eucalyptus grandis, that the resistance does not follow a normal distribution and that the lognormal distribution was better suited to the data under study. The research also indicated a coefficient of variation equal to $26,5 \%$.

Logsdon et al. (2010) found through tests of 100 specimens of Angelim Pedra (Dinizia excelsa), that the distribution of compressive strength parallel to the fibers does not follow a normal distribution, but is equivalent. It was also observed that the upper limit of the coefficient of variation of the distribution of compressive strength parallel to the fibers was close to $18 \%$.

The available literature presents few results about the evaluation of the distribution of wood compressive strength parallel to the fibers, as well as on the variability of these values, represented by the coefficient of variation. The data presented in Brazilian Standard of timber structures were obtained based on the analysis of few wood species and the literature consulted by the authors found the study of only two species of wood, the Eucalyptus grandis and the Angelim Pedra. It is, therefore, important the evaluation of more wood species.

This work evaluates the type of distribution followed by compressive strength parallel to the wood fiber, as well as the coefficient of variation for this property. A greater number of species was used than in the consulted literature, encompassing species of the hardwood group commonly used in timber structures in the Brazilian market; including: Casca Grossa (Vochysia spp.), Cupiúba (Goupia glabra), Ipê (Tabebuia serratifolia), Jatobá (Hymenaea spp.), Pequiá (Caryocar villosum), Peroba do Campo (Paratecoma peroba), and Peroba Rosa (Aspidosperma polyneuron).

\section{MATERIAL AND METHODS}

Compression tests were performed parallel to the wood fibers following the methodology for defect-free specimens presented in the project of ABNT standard PNBR - 02:126.10-001-1 (ABNT 2013a). The experimental analysis was carried out in the Wood and Timber Structures Laboratory of the Structures Department of the São Carlos School of Engineering (LaMEM/SET/EESC).

The samples were cut randomly from sawn pieces. The specimens were taken at a distance from the edge 5 times the smallest cross section dimension, since greater than $30 \mathrm{~cm}$, following PNBR - 02:126.10-001-1 (ABNT 2013a) recommendations.

The specimens with square cross section with $5 \mathrm{~cm}$ side and length equal to $15 \mathrm{~cm}$, were tested to compression parallel to the fibers in the Amsler universal machine, following the cycle of loading and unloading presented in PNBR - 02:126.10-001-1 (ABNT 2013a). In this cycle, the test body is loaded up to $50 \%$ of its rupture force, remaining for $30 \mathrm{~s}$. at this loading level. Then the load is reduced to $10 \%$ of the rupture force, remaining at this loading level for another $30 \mathrm{~s}$. After this phase, the force is elevated until the rupture of the structural element.

After the compression tests, the specimens were placed in an oven with a maximum temperature of 103 ${ }^{\circ} \mathrm{C} \pm 2{ }^{\circ} \mathrm{C}$ for drying and subsequent determination of moisture. The compressive strength was corrected to the humidity of $12 \%$ from the ratio present in NBR 7190 (ABNT 1997), presented in Equation 1.

$$
f_{12}=f_{u \%}\left[1+\frac{3(U \%-12}{100}\right]
$$
$U \%$.

In Equation $1, f_{12}$ is the resistance of wood with $12 \%$ moisture, $f_{u^{\circ}}$ is the resistance of wood in moisture 
The species used in this work, as well as the amount of test specimens of compressive strength parallel to the fibers for each species, are presented in Table 1.

Table 1: Quantity of compressive strength test specimens parallel to the fibers.

\begin{tabular}{|c|c|c|}
\hline Species & Scientific name & Amount of test specimens \\
\hline Casca Grossa & Vochysia spp. & 34 \\
\hline Cupiúba & Goupia glabra & 34 \\
\hline Ipê & Tabebuia serratifolia & 34 \\
\hline Jatobá & Hymenaea spp. & 35 \\
\hline Pequiá & Caryocar villosum & 35 \\
\hline Peroba do Campo & Paratecoma peroba & 33 \\
\hline Peroba Rosa & Aspidosperma polyneuron & 35 \\
\hline \multicolumn{2}{|c|}{} & 240 \\
\hline
\end{tabular}

After the experimental analyses, statistical analyses were performed with the aid of the program SISVAR (Ferreira 2011). For each of the tested species, the normality of the strength distribution was verified by means of the Shapiro-Wilk (S-W) and Kolmogov-Smirnov (K-S) tests. Also determined were the mean values, characteristic (NBR 7190) and Coefficients of variation of the compressive strength parallel to the fibers of the wood.

The Shapiro-Wilk test, proposed in 1965 , is based on a statistic (W) calculated on the squared ordered sample values, seeking to assess whether a random sample originates from a Normal distribution (Shapiro and Wilk 1965).

The Kolmogorov-Smirnov normality test, statistic (D), for a sample is an adherence test, ie it checks the degree of agreement between the distribution of a set of sample values and a specific theoretical distribution.

According to Torman et al. (2012) the S-W and K-S tests provide the parameter value of the test (p-value (W and D), p-value or significance), which can be interpreted as the measurement of the degree of concordance between the data and the null hypothesis ( $\mathrm{H} 0)$, and $\mathrm{H} 0$ corresponds to the Normal distribution. The value of W and D refers to the statistics of Shapiro-Wilk and Kolmogorov-Smirnov, respectively.

The test part of the null hypothesis (H0) considering the distribution of the data to be Normal. Given a level of significance, usually established in $5 \%$ if the test rejects the hypothesis, then the distribution of the data is not normal. That is, if the P-value is less than the established level $5 \%$, then there are indications to discard the normality of the data. On the other hand, if the P-value of the test is above the $5 \%$ established, or another pre-defined level, this means that the hypothesis of normality cannot be rejected. For each species, the resistance values obtained experimentally were divided by the mean value of the type. This was done to enable the grouping of all data and consequently, to obtain a single coefficient of variation for all species in relation to the compressive strength parallel to the wood fibers.

The confidence interval (CI) of the coefficients of variations was also obtained, with the purpose of verifying the reliability of the estimates (probable range of estimates), using a coefficient of confidence equal to $95 \%$.

\section{RESULTS AND DISCUSSION}

In Table 2, the compressive strength parallel to the fibers is presented after correction to the reference humidity of $12 \%\left(\mathrm{f}_{\mathrm{c} 0.12}\right)$, obtained in the tests of the 7 species analyzed. In Table 3, the normality test of the distribution of compressive strength parallel to the fibers of the 7 species analyzes is presented. 
Table 2: Compressive strength parallel to the fibers $\left(f_{c 0,12}\right)$ of the specimens in ascending position (moisture content of $12 \%)$.

\begin{tabular}{|c|c|c|c|c|c|c|c|c|c|c|}
\hline Specie & \multicolumn{10}{|c|}{$\mathrm{f}_{\mathrm{c} 0,12}(\mathrm{MPa})$} \\
\hline \multirow{4}{*}{$\begin{array}{l}\text { Casca } \\
\text { Grossa }\end{array}$} & 82 & 87 & 89 & 93 & 93 & 95 & 98 & 103 & 105 & 106 \\
\hline & 108 & 109 & 113 & 115 & 116 & 117 & 120 & 121 & 125 & 129 \\
\hline & 130 & 131 & 133 & 135 & 136 & 141 & 142 & 143 & 145 & 150 \\
\hline & 155 & 161 & 167 & 195 & & & & & & \\
\hline \multirow{4}{*}{ Cupiúba } & 30 & 34 & 35 & 39 & 39 & 39 & 41 & 42 & 42 & 46 \\
\hline & 46 & 47 & 47 & 48 & 49 & 50 & 50 & 51 & 51 & 51 \\
\hline & 56 & 58 & 58 & 59 & 61 & 61 & 63 & 66 & 66 & 66 \\
\hline & 69 & 71 & 73 & 73 & & & & & & \\
\hline \multirow{4}{*}{ Ipê } & 50 & 54 & 55 & 56 & 59 & 62 & 64 & 68 & 69 & 70 \\
\hline & 72 & 72 & 73 & 74 & 74 & 77 & 77 & 77 & 78 & 78 \\
\hline & 78 & 80 & 80 & 80 & 82 & 82 & 83 & 84 & 84 & 85 \\
\hline & 85 & 88 & 93 & 99 & & & & & & \\
\hline \multirow{4}{*}{ Jatobá } & 75 & 78 & 80 & 80 & 85 & 85 & 88 & 88 & 90 & 91 \\
\hline & 91 & 92 & 92 & 92 & 92 & 93 & 94 & 95 & 95 & 96 \\
\hline & 96 & 96 & 97 & 97 & 98 & 98 & 99 & 102 & 102 & 103 \\
\hline & 103 & 104 & 105 & 106 & 109 & & & & & \\
\hline \multirow{4}{*}{ Pequiá } & 28 & 32 & 32 & 33 & 33 & 34 & 34 & 35 & 36 & 36 \\
\hline & 37 & 37 & 37 & 38 & 38 & 38 & 39 & 39 & 39 & 40 \\
\hline & 41 & 42 & 42 & 42 & 43 & 43 & 44 & 44 & 45 & 48 \\
\hline & 50 & 50 & 51 & 52 & 58 & & & & & \\
\hline \multirow{4}{*}{$\begin{array}{l}\text { Peroba } \\
\text { do } \\
\text { Campo }\end{array}$} & 37 & 43 & 44 & 46 & 46 & 46 & 48 & 48 & 49 & 50 \\
\hline & 51 & 51 & 51 & 51 & 51 & 51 & 52 & 54 & 54 & 57 \\
\hline & 59 & 59 & 59 & 59 & 60 & 60 & 61 & 65 & 65 & 66 \\
\hline & 66 & 72 & 77 & & & & & & & \\
\hline \multirow{4}{*}{$\begin{array}{c}\text { Peroba } \\
\text { Rosa }\end{array}$} & 31 & 36 & 39 & 40 & 40 & 42 & 43 & 44 & 46 & 47 \\
\hline & 47 & 47 & 48 & 50 & 49 & 52 & 52 & 53 & 53 & 53 \\
\hline & 53 & 55 & 56 & 56 & 57 & 60 & 61 & 61 & 62 & 64 \\
\hline & 64 & 65 & 65 & 66 & 69 & & & & & \\
\hline
\end{tabular}

Based on the results, presented in Table 3, of the S-W and K-S, with $95 \%$ confidence, tests, it is possible to decide the normality of all samples ( $\mathrm{W} \cong 1, \mathrm{pr}<\mathrm{W}>5 \%$ and $\mathrm{D} \cong 0, \mathrm{pr}<\mathrm{D}>5 \%$ ), since the obtained values of significance, $p$-value, of the tests is above the $5 \%$ established. It was possible to confirm the statement in the Brazilian standard of timber, NBR 7190 (ABNT 1997), that the wood resistance follows a normal distribution. The test results are corroborated by the frequency histograms and polygons of Figure 1 and Figure 2 as they approach the normal distribution curve.

Table 3: Results of the normality tests of the distribution of the samples.

\begin{tabular}{|c|c|c|c|c|}
\hline \multirow{2}{*}{ Species } & \multicolumn{4}{|c|}{ Tests } \\
\cline { 2 - 5 } & \multicolumn{2}{|c|}{ Shapiro - Wilk } & Kolmogorov - Smirnov \\
\cline { 2 - 5 } & $\mathrm{W}$ & $\mathrm{pr}<\mathrm{W}$ & $\mathrm{D}$ & $\mathrm{pr}<\mathrm{D}$ \\
\hline Casca Grossa & 0,9699 & 0,4611 & 0,0662 & 0,9976 \\
\hline Cupiúba & 0,9671 & 0,3857 & 0,1308 & 0,5756 \\
\hline Ipê & 0,9641 & 0,3197 & 0,1372 & 0,5131 \\
\hline Jatobá & 0,9718 & 0,4951 & 0,1033 & 0,8288 \\
\hline Pequiá & 0,9626 & 0,2732 & 0,1201 & 0,6653 \\
\hline Peroba do Campo & 0,9683 & 0,4354 & 0,1518 & 0,4022 \\
\hline Peroba Rosa & 0,9781 & 0,6963 & 0,0823 & 0,9650 \\
\hline
\end{tabular}

The 7 species studied, the following results were obtained: arithmetic mean of the samples $\left(\mathrm{f}_{\mathrm{co,m}}\right)$; Characteristic resistance of the population, admitting quantile of $5 \%,\left(\mathrm{f}_{\mathrm{c} 0, \mathrm{k}}\right)$ and coefficient of variation $(\delta)$. These values are shown in Table 4. In Figure 1 and Figure 2, histograms and frequency polygons are presented for the species Casca Grossa and Peroba Rosa, respectively. The histograms and frequency polygons of the other species were omitted for the sake of space. 
Table 4: Statistical analysis of the tested species.

\begin{tabular}{|c|c|c|c|c|c|c|c|}
\hline \multirow{2}{*}{ Results } & \multicolumn{7}{|c|}{ Species } \\
\cline { 2 - 8 } & $\begin{array}{c}\text { Casca } \\
\text { Grossa }\end{array}$ & Cupiúba & Ipêe & Jatobá & Pequián & $\begin{array}{c}\text { Peroba } \\
\text { do } \\
\text { Campo }\end{array}$ & $\begin{array}{c}\text { Peroba } \\
\text { Rosa }\end{array}$ \\
\hline $\mathrm{f}_{\mathrm{c} 0, \mathrm{~m}}(\mathrm{MPa})$ & 123,18 & 52,26 & 74,76 & 93,91 & 40,29 & 54,79 & 52,14 \\
\hline $\mathrm{f}_{\mathrm{c} 0, \mathrm{k}}(\mathrm{MPa})$ & 85,50 & 32,80 & 52,80 & 77,25 & 31,00 & 40,90 & 34,75 \\
\hline$\delta(\%)$ & 20,72 & 22,64 & 15,11 & 8,69 & 16,37 & 16,02 & 18,17 \\
\hline
\end{tabular}

To ascertain the value of the coefficient of variation recommended by NBR 7190 (ABNT 1997) and confirmed by Kretschmann (2010), which is worth $18 \%$, the confidence interval was performed, using the confidence coefficient equal to $95 \%$ with the values of coefficients of variation of the 7 species analyzed. A confidence interval between $12,67 \%$ and $20,97 \%$ was obtained, with a mean value equal to $16,82 \%$. Thus, the quoted value is within the confidence interval and very close to the value of $18 \%$ obtained, so that it can be considered a representative value for the calculation of the characteristic resistance to the wood compression, as proposed by NBR 7190 (ABNT 1997).

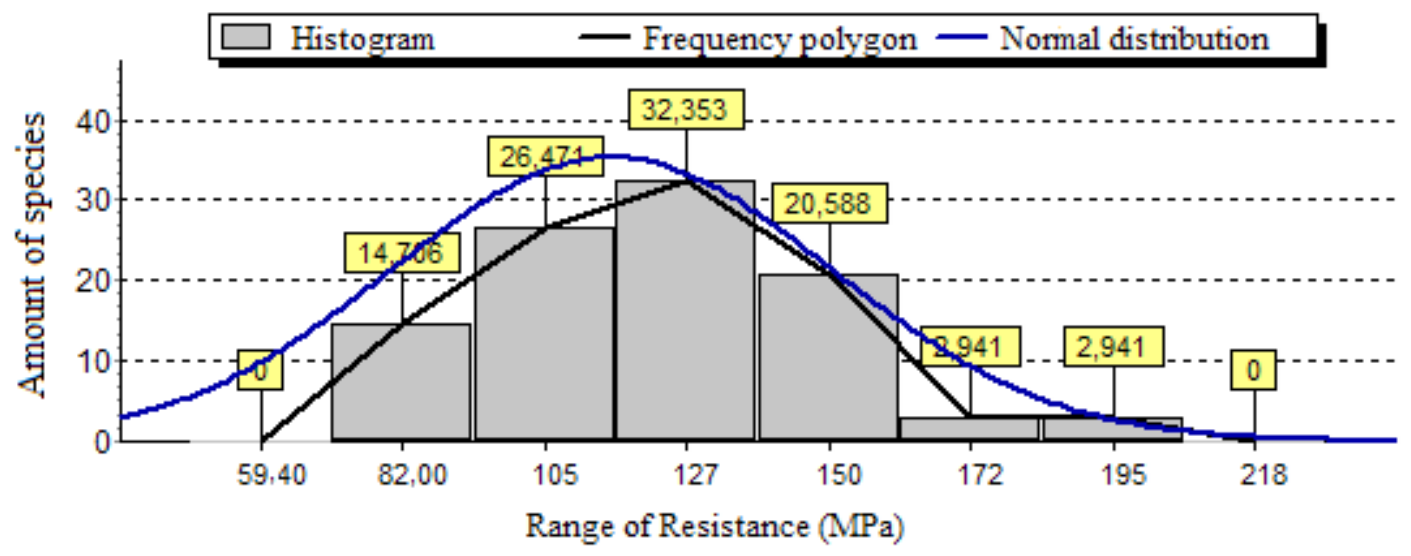

Figure 1: Histogram and frequency polygon of the species Casca Grossa.

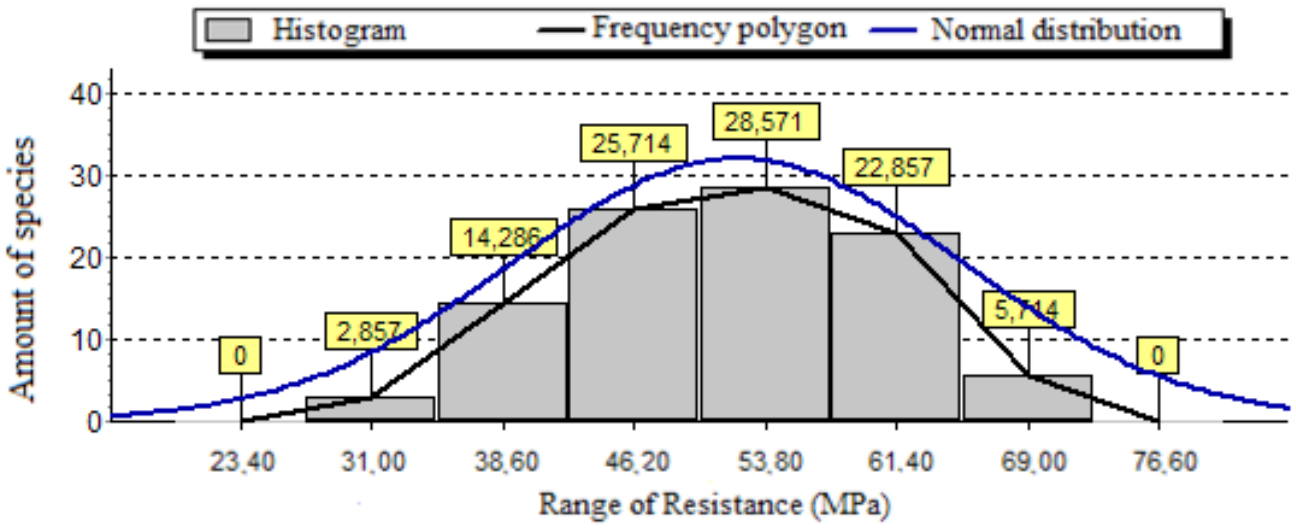

Figure 2: Histogram and frequency polygon of Peroba Rosa species. 
It is possible to observe in the results presented in Table 4 that Casca Grossa and Cupiúba were the species presented the highest coefficients of variation, being even higher than $18 \%$. These species have reverses fibers (fibers not parallel to the workpiece axis), or irregular grain, due to the irregular or very fast growth of wood, a common fact in tropical species. This fact according to de Souza-Almeida et al. (2018), can lead to higher coefficients of variation.

Alternatively, we proceeded with the data of the 7 species in order to obtain a single coefficient of variation. For this purpose, the ratios of compressive strength of 240 samples were used for their respective values. With the aid of the SISVAR software, the coefficient of variation of the data was calculated, obtaining a value equal to $17,11 \%$, and the histogram and frequency polygon were generated as shown in Figure 3.

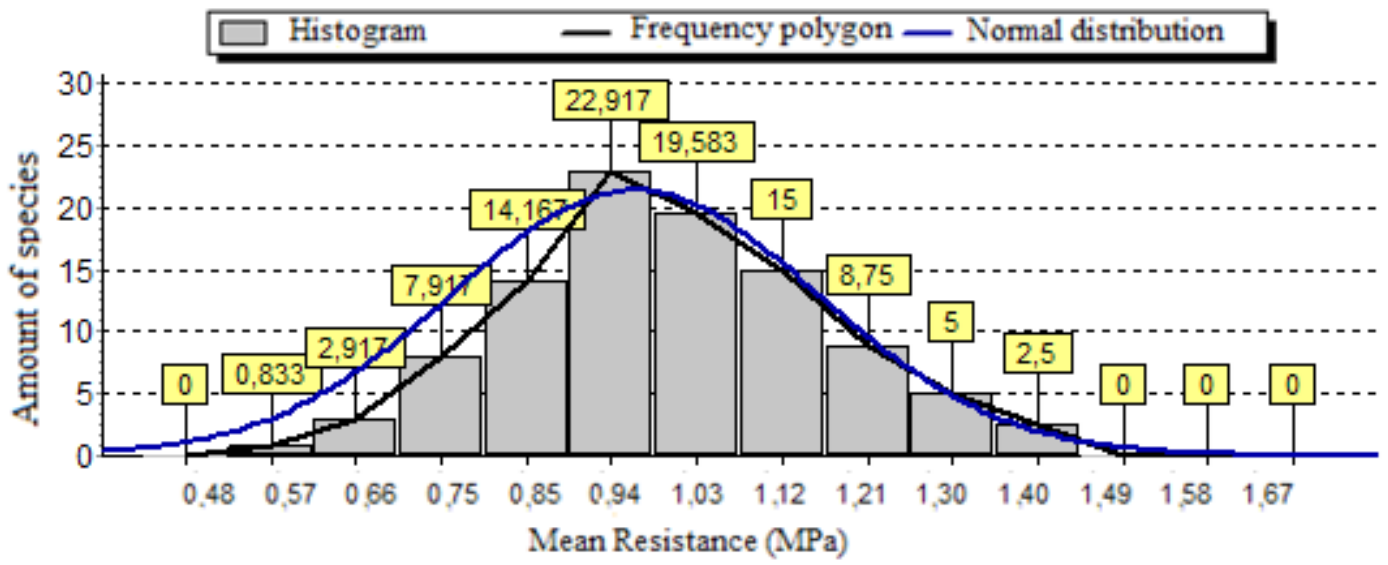

Figure 3: Histogram and frequency polygon for resistance/mean value for all 7 species.

\section{CONCLUSIONS}

In this research, the normality of the distribution of compressive strength parallel to the wood fibers was confirmed for 7 species of wood using the Shapiro-Wilk and Kolmogorov - Smirnov normality tests.

The results corroborated the methodology presented in the NBR 7190, which considers the resistances of wood as random variables that can be represented by the Normal distribution, Gauss curve, and that its characteristic values correspond to the Quantile of $5 \%$ of the respective distribution.

This work also addressed the coefficient of variation of compressive strength parallel to the wood fibers. Two methodologies were used for this analysis, and two coefficient of variation values were used: in the first, the mean variation coefficients of the 7 species were considered and the confidence interval was also determined, while in the second the 7 species were grouped, considering the ratio between resistance and average resistance of each species and the set of data formed was obtained a single coefficient of variation for the sample.

For the first methodology, a mean coefficient of variation of $16,82 \%$ was found in a confidence interval between $12,67 \%$ and $20,97 \%$. The second methodology provided a coefficient of variation equal to $17,11 \%$. The value recommended by the Brazilian standard of timber structures is within the confidence interval determined using the first methodology, and is slightly higher than the value obtained using the second methodology. Thus, it is concluded that the adoption of the coefficient of variation equal to $18 \%$ is acceptable. 


\section{REFERENCES}

Aquino, V.B. de M.; Almeida, J.P.B.; Almeida, D.H.; Almeida, T.H.; Panzera, T.H.; Christoforo, A.L.; Lahr, F.A.R. 2018. Physical and Mechanical Characterization of Copaifera sp. Wood Specie. Int J Mater Eng 8(3): 55-58. https://doi.org/10.5923/j.ijme.20180803.03.

ABNT. 1997. NBR 7190: Projetos de estruturas de madeiras. ABNT. Rio de Janeiro, Brazil.

ABNT. 2013a. PNBR 02:126.10-001-1 Madeiras - Método de Ensaio de caracterização de corpos de prova isentos de defeitos para madeiras tropicais. Projeto de Revisão, ABNT. Rio de Janeiro, Brazil.

ABNT. 2013b. PNBR 7190: Projeto de Estruturas de Madeira. Projeto de Revisão. Rio de Janeiro, Brazil.

Couto, N.G.; Aquino, V.B. de M.; Almeida, J.P.B.; Almeida, D.H.; Christoforo, A.L.; Lahr, F.A.R. 2018. Determination of Physical and Mechanical Properties of Wood Specie Dinizia excelsa Ducke. Int J Mater Eng 8(6): 158-161. https://doi.org/10.5923/j.ijme.20180806.04 .

CEN. 2016. UNE-EN 14358: Timber Structures - Determination and verification of characteristic values. AENOR, Madrid, Spain. (in Spanish).

de Souza-Almeida, A.; Lanini, T.L.S.; Caetano, J.A.; Christoforo, A.L.; Lahr, F.A.R. 2018. Evaluation of Stiffness in Compression Perpendicular to Grain of Brazilian Tropical Wood Species. Current J Appl Sci Eng Technol 28(5): 1-7. https://doi.org/10.9734/CJAST/2018/42945.

Espinosa, M.M.; Calil Junior, C.; Lahr, F.A.R. 2004. Parametric and non-parametric methods to determine the characteristic value in wood tests results. Sci For 66: 76-83. (in Portuguese). https://www.ipef.br/ publicacoes/scientia/nr66/cap07.pdf.

Ferreira, D.F. 2011. Sisvar: a computer statistical analysis system. Cienc Agrotec 35(6): 1039-1042. http://dx.doi.org/10.1590/S1413-70542011000600001.

Kretschmann, D.E. 2010. Mechanical Properties of Wood. In Wood Handbook: Wood as an engineering material (Chapter 5: 5.1-5.46.) Department of Agriculture, Forest Service, Forest Products Laboratory, WI, USA. https://www.fpl.fs.fed.us/documnts/fplgtr/fpl_gtr190.pdf.

Gherardi Hein, P.R.; Tarcísio Lima, J. 2012. Relationships between microfibril angle, modulus of elasticity and compressive strength in Eucalyptus wood. Maderas-Cienc Tecnol 14(3): 267-274. http://dx.doi. org/10.4067/S0718-221X2012005000002.

Koman, S.; Feher, S.; Vityi, A. 2017. Physical and mechanical properties of Paulownia tomentosa wood planted in Hungaria. Wood Res 62(2): 335-340. http:/www.woodresearch.sk/wr/201702/15.pdf.

Lima, T.F.P.; Almeida, T.H.; Almeida, D.H.; Christoforo, A.L.; Lahr, F.A.R. 2018. Physical and mechanical properties of Tatajuba wood specie (Bagassa guianensis) from two different Brazilian regions. Matéria (Rio J.) 23(3): e12185. (in Portuguese) http://dx.doi.org/10.1590/s1517-707620180003.0519.

Lima Junior, M.P.; Biazzon, J.C.; Araujo, V.A.; Munis, R.A.; Martins, J.C.; Cortez-Barbosa, J.; Gava, M.; Valarelli, I.D.; Morales, E.A.M. 2018. Mechanical Properties Evaluation of Eucalyptus grandis Wood at Three Different Heights by Impulse Excitation Technique (IET). Bioresources 13(2): 3377-3385. https://ojs.cnr.ncsu.edu/index.php/BioRes/article/view/BioRes_13_2_3377_Lima_Mechanical_Properties_ Evaluation_Eucalyptus.

Logsdon, N.B.; Jesus, M.H.; Penna, J.E. 2010. Evaluation of the estimators of the characteristic strength to compression parallel to the grain. Sci For 38(88): 579-587. (in Portuguese) https://www.ipef.br/publicacoes/ scientia/nr88/cap04.pdf.

Pinto, E.M.; Espinosa, M.M.; Calil Junior, C. 2004. Methods for determining the characteristic value of the compression resistance parallel to the wood fibers. Madeira: Arquitetura e Engenharia 5(14): 1-6. (in Portuguese) http://madeira.set.eesc.usp.br/article/view/264.

Shapiro, S.S.; Wilk, M.B. 1965. An Analysis of Variance Test for Normality (Complete Samples). Biometrika 52(3/4): 591-611. https://doi.org/10.2307/2333709.

Silva, C.E.G.; Almeida, D.H.; Almeida, T.H.; Chahud, E.; Branco, L.A.M.N.; Campos, C.I.; Lahr, 
F.A.R.; Christoforo, A.L. 2018. Influence of procurement site on physical and mechanical properties of $\mathrm{Cu}-$ piúba Wood Species. Bioresources 13(2): 4118-4131. http://dx.doi.org/10.15376/biores.13.2.4118-4131.

Torman, V.B.L; Coster, R.; Riboldi, J. 2012. Normality of variables: diagnosis methods and comparison of some nonparametric tests by simulation. Rev HCPA 32(2): 227-234. (in Portuguese) https://seer.ufrgs.br/ hcpa/article/view/29874/19186.

Zeidler, A.; Salem, M.Z.M.; Boruvka, V. 2014. Mechanical properties of grand fir wood grown in the Czech Republic in vertical and horizontal positions. Bioresources 10(1): 793-808. https://ojs.cnr.ncsu.edu/ index.php/BioRes/article/view/BioRes_10_1_783_Zeidler_Properties_Grand_Fir_Wood/3247. 